\title{
Use of Social Networking Sites at Workplace in Bangladesh: Employees' Perspective
}

\section{Tabassum Siddique}

Assistant Professor, Department of Business Administration, International Islamic University Chittagong, BANGLADESH

*Corresponding Contact:

Email: tabs_06@hotmail.com

Cell Phone: +8801715755557

\begin{abstract}
The growing use of online social networking in today's business activities have become an integral part of a modern organization in Bangladesh. It has recently taken the place of real life social networks and communication in all aspects of life. The cheap availability of Internet through the computer, Laptop and some other handheld devices provided by most of the modern private organizations, are giving its employees a privilege of getting easy access to their personal and professional social networking sites at home and at work. Organizations spend money for such purposes as an investment on a strategic tool for enhancing the productivity of its employees. Social networking sites at the workplace carry enormous benefits and some drawbacks as well. This could hinder organizational productivity and reputation if not managed effectively. One of the prominent managerial tools is organizational policy regarding the use of social networking sites at work. The present study attempts to investigate the usage, activities and impacts of using social networking sites by the employees at the workplace. The study also intends to guide the employers to introduce a reasonably fair guidance that will be acceptable by both the parties. The study used a sample of 180 employees working at different organizations in Dhaka city. Proper guidance, educating and training employees about the security issues for the organization, allowing employees time based access, etc. are some of the major recommendations made by this paper that can work for the company without limiting the employee freedom.
\end{abstract}

Key Words: Social networking, social media

\section{INTRODUCTION}

Recently modern organizations are using the social media as a tool to communicate with its employees and customers. Besides these, companies also conduct some of their major HR functions, such as recruitment and selection of employees, etc. through the social media. The emergence and the wide acceptance of social networking sites in today's communities has seemed to be revolutionized human behavior, lifestyle and thinking regardless of age, sex or 
location. In Bangladesh, it has recently taken the place of real life social networks and communication. Social networking sites such as; Facebook, Linkedin and Twitter etc., are the most popular social networking sites nowadays which are commonly used on daily basis by most of the internet population to interact with their families and friends. Besides the individuals in today's businesses are also seem to be mesmerized with the power of online social networking tools to build business communication and appearance. Although social networking sites were built with a great intention to extend and improve human communication abilities, the excessive use of social networking sites has raised the possibility to facilitate deception, social grooming and the creation of defamatory content in the community. Now a day, a modern private organization, has made the use of Internet very cheap and easily accessible through the computer, laptop and some other handheld devices. Organizations provide these benefits so that their employees can use them to enhance a better relational experience with their peers, coworkers, channel members and customers. These are giving its employees a privilege of getting easy access to their personal and professional social networking sites at home and at work. Organizations spend money for such purposes as an investment on a strategic tool for enhancing the productivity of its employees. Though mobile devices are an organizational asset; they are often not subject to the same controls and monitoring as the enterprise's computers. However, employee's use of social networking sites, while they are on job raises certain ethical concern and responsibilities. These should be considered with utmost priority in order to maintain and ensure good morality, righteousness and virtue among the employees of an organization.

Apart from this, the increasing use of social network in the workplace presents some concern for employers. Under these above circumstances, if social networking is completely blocked at the workplace, employees would most likely be able to find ways to get around the controls. There are many other ways to access blocked websites online. Different websites grant access to blocked sites. Not only would Information Technology Administrators have to block the main social networking websites, but they would also have to block the proxy websites as well. It would be effective if the management can establish a clear and thorough policy regarding the use of various online sites and activities at the workplace. An organizational success stems from a coordinated effort by the employer and employee. Thus the present study will help the employers to introduce a reasonably fair guidance that will be acceptable by both the parties. The present study also intends to examine the effect of social networking sites on corporate culture and corporate information security policies.

\section{Research ObJectives}

The present study attempts-

- To disclose the usage status of Social networking sites at the workplace regarding gender and age group.

- To explore the existence of Social networking policy in the organization and the effective enforcement of the policy from the employee perspective.

- To exhibit the employee opinion regarding the impact of using SNS at the workplace as well as to develop their recommendations regarding Social networking policy for the organization.

\section{LITERATURE REVIEW}

Social networking sites are defined by Boyd \& Ellison (2007) as "web-based services that allow individuals to construct a public or semi-public profile within a bounded system, to articulate a list of other users with whom they share a connection with, and to view and 
traverse their list of connections and those made by others within the system. Ellison, Steinfield, and Lampe (2007) classified social networking sites into several categories: workrelated contexts such as Linkedin, romantic relationship such as Friendster, people with common interests such as MySpace, and college students such as Facebook.

Studies have so far been conducted on the use and impact of Social networking sites by people. But a limited number was found to cover the employer and employee perspectives, especially in the context of Bangladesh. Several previous studies have shown various impact of employees' use of social networking sites at workplace, such as; unauthorized postings (Wise, 2009), weakening productivity, security risks to the company by sharing data externally(Peacock, 2008). According to Breslin, (2009, Employers have the right to hold employees responsible for such conduct if the postings are used to 'attack the company' or 'harass co-workers'". Leidner, et al. (2010) found that an internal social networking system at an investment/insurance firm based in USA helped elevate new hires retention rate. Patel and Jasani (2010) offer several guidelines that can be used by businesses when establishing corporate social media policies that can ensure social media security.

According to a survey of more than 1,400 CIOs conducted by Robert Half Technology (2009), about one in every five companies in the U.S. allow the use of social networking sites for business purpose while only one in ten companies allow the use of social networking at the workplace for personal use. In fact, reasonable access to social networks can increase productivity (AT\&T, 2008; Bennett, Owers, Pitt, \& Tucker, 2010). A European study commissioned by AT\&T in 2008 found that 65 percent of employees believed that the use of social networking helped them be more productive (AT\&T, 2008). Social networking can have benefits as well as drawbacks on the workplace. Bennett, et al. (2010) argued that the business benefits of social networking in the workplace outweigh the negative perceptions. But these benefits are still undervalued by many organizations although some organizations started to adopt social networking as part of their strategic tool. A global survey was conducted by Manpower Inc. (NYSE:MAN) in October, 2009, where over 34000 employers in 35 countries and territories of America, Asia Pacific, Europe, Middle East and Arica. The survey was attempted to disclose the employer attitudes toward the use of external social media in the workplace. The survey result revealed that $75 \%$ of the employers surveyed indicated that their organization have no policy regarding the use of external social networking sites in the workplace. Only $20 \%$ of the sample employers responded that their organizations have policies in place to regulate the use of external social networking sites in the workplace. Among them the majority $(63 \%)$ of the employers found that their policies were effective in helping to avoid productivity loss, and 33\% indicated that it was effective as they are able to protect their intellectual property and other proprietary information. That survey result also showed that $89 \%$ of the employers said that the employees' use of social network at workplace did not damage their organization's reputation (Manpower Inc., 2009).

In Bangladesh recently the phenomenon of using social networking by the new generation workforce is rapidly transforming the nature and scope of work. This generation has just stepped into the workforce, soon will make up the majority of employees in every company. Hence, this is the right time for the management to formulate a full-fledged policy for observing, controlling and for monitoring the employees' use of social networking sites at the workplace.

\section{Methodology}

The study used a sample of 180 employees working at different organizations in Dhaka city. The sample was drawn from different industry; namely: Education, Pharmaceutical, Real Estate, Telecommunication, FMCGs and Banking sector irrespective of gender and designation. 
30employees were selected from each industry by using judgment sampling approach that is based on easy accessibility of the sample. The total population size was unknown due to unavailability of data regarding social network usage of the total workforce of Bangladesh. Data was collected through a closed ended questionnaire. Non-probability study method was used for the survey. Face to face interviews were scheduled with respondents so that the researcher could question the participants through observation and interaction. The data were analyzed by using frequency distribution, descriptive statistics and cross tabulation. The secondary data were collected from consulting various documents, reports, articles, case studies, books, and internet and so on. The collected data were analyzed keeping in mind the objectives of the study. The period of the study is January 2014 to November 2014.

\section{FINDINGS AND ANALYSIS}

Among the 180 sample respondents, $65 \%$ is Male and 35\% is Female employees. Employee perspectives were collected in three parts. First, the usage status of social networking sites has been presented. In the second part, the presence of organizational policies and impact regarding the use of social networking sites by the employees at the workplace has been shown. Finally employees' opinions regarding different policy suggestions have been presented.

\section{Usage status of social networking sites}

Table 1: Percentage (\%) of Employees' Use of SNS Account

\begin{tabular}{|l|c|}
\hline Name of SNS & Responses in $\%$ \\
\hline Facebook & $75 \%$ \\
\hline Linkedin & $13.3 \%$ \\
\hline Netlog & $2.33 \%$ \\
\hline Twitter & $6.70 \%$ \\
\hline My Space & $2.00 \%$ \\
\hline Other & $0.67 \%$ \\
\hline
\end{tabular}

\begin{tabular}{|l|c|c|}
\hline Usage & Male (in \%) & Female (in \%) \\
\hline Single SNS user & $95.4 \%$ & $98.3 \%$ \\
\hline Multiple SNS user & $4.6 \%$ & $1.7 \%$ \\
\hline Total & $100 \%$ & $100 \%$ \\
\hline
\end{tabular}

Among the Social networking sites Majority (75\%) of the sample respondents use Facebook, 13\% use Linkedin. The data also reveals that respondents are largely the user of single SNS account.

Table 2: Gender wise Frequency of using social networking in the workplace

\begin{tabular}{|l|c|c|c|}
\hline Frequency of use & Male (in \%) & Female (in \%) & Total (in \%) \\
\hline Daily several times & 40 & 18 & 38.7 \\
\hline Daily once & 25 & 14 & 26.0 \\
\hline Weekly several times & 5 & 1 & 4.0 \\
\hline Weekly & 2 & 1 & 2.0 \\
\hline Monthly & 2 & 2 & 2.7 \\
\hline Irregular & 11 & 3 & 9.3 \\
\hline Don't use & 21 & 5 & 17.3 \\
\hline
\end{tabular}


$38.7 \%$ of the sample employees use social networking sites at office daily several times. $26 \%$ visit at least once in a day. Whereas; $17.3 \%$ of the employees mentioned that they don't visit their personal social networking sites at office. In other words, it can also be said that majority $(82.7 \%)$ of the sample employees visit their personal social networking sites while they are at the office.

Table 3: Purposes of using social networking in the workplace

\begin{tabular}{|l|c|}
\hline Frequency of use & Total Responses (in \%) \\
\hline Personal communication & $74 \%$ \\
\hline Office communication & $16.7 \%$ \\
\hline $\begin{array}{l}\text { Personal communication and office communication with } \\
\text { separate account }\end{array}$ & $9.3 \%$ \\
\hline
\end{tabular}

The study shows that a large number of respondents $(74 \%)$ use social networking at the workplace for communicating with their family and friends, spending time with chatting, sharing and uploading photographs and passing comments. Therefore, they were wasting productive work hours. Whereas, $16.7 \%$ sample employees use social networking sites only as part of their office communication. And $9.3 \%$ use both corporate and personal sites simultaneously.

Table 4: Devices to get access to social networking in the workplace

\begin{tabular}{|l|c|c|}
\hline Devices & Office & Personal (in \%) \\
\hline Computer & $17.6 \%$ & 00 \\
\hline Mobile & $3 \%$ & $68.2 \%$ \\
\hline Other handheld & $1.1 \%$ & $10.1 \%$ \\
\hline
\end{tabular}

Most of the respondents (78\%) were found to use their personal mobile and other handheld devices to visit social networking sites when they are in office. Only $21.7 \%$ of sample employees use office LAN, Office Computer, Laptop and Mobile those were provided by the company.

Table 5: Use of SNS at workplace under different Age group

\begin{tabular}{|c|c|c|c|c|}
\hline $\begin{array}{c}\text { Age group } \\
\text { (in Years) }\end{array}$ & $\begin{array}{c}\text { Heavy user (in \%) } \\
\text { (several times in a day) }\end{array}$ & $\begin{array}{c}\text { Light user (in \%) } \\
\text { (Once in a day) }\end{array}$ & $\begin{array}{c}\text { Minimum User (in\%) } \\
\text { (Once or twice in } \text { } \text { month) }\end{array}$ & $\begin{array}{c}\text { Total respondents } \\
\text { in \% }\end{array}$ \\
\hline $25-35$ & 55 & 9 & 13 & $77 \%$ \\
\hline $35-45$ & 12.7 & 4.7 & 4.0 & $21.3 \%$ \\
\hline $45-55$ & 1.3 & 0 & 0 & $1.3 \%$ \\
\hline Total & 69 & 14 & 17 & $100 \%$ \\
\hline
\end{tabular}

The result of the study revealed that Majority $(77 \%)$ of the sample respondents' fall within the age group of 25 to 35 years. Only 1.3\% of sample employees responded that they use social networking sites at the office. More than half $(69 \%)$ of sample respondents are the heavy users of SNS during office hour, where 55\% belong to 25-35 years age group. Only $1.3 \%$ users belong to $45-55$ years of age group and all of them are heavy user. 
Figure 1: Use of SNS at workplace under different Age group

\section{Age Distribution with regard to Frequency of using SNS at workplace}

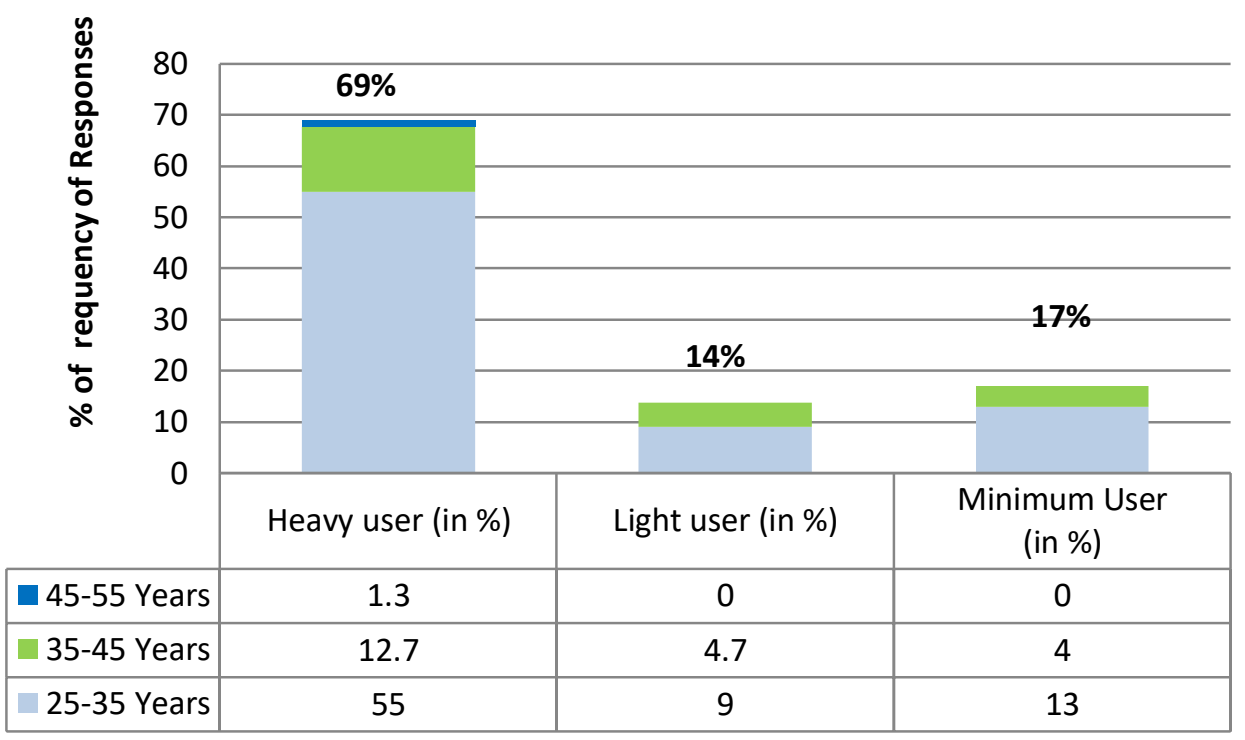

Impact of using social networking sites at workplace: Employees' perspective

\begin{tabular}{|l|c|c|c|}
\hline Employee agreeableness about the impact Factor & Agree (in \%) & Disagree (in \%) & Neutral \\
\hline Negative effect on organization reputation & $22.7 \%$ & $46 \%$ & $31.3 \%$ \\
\hline Employee morale is decreased & $25.3 \%$ & $42 \%$ & $32.7 \%$ \\
\hline company can face lawsuits, bad publicity & $24 \%$ & $34.7 \%$ & $41.3 \%$ \\
\hline Negative effect in Productivity & $28 \%$ & $50.7 \%$ & $21.3 \%$ \\
\hline Harass coworker & $15.3 \%$ & $36.7 \%$ & $47.3 \%$ \\
\hline
\end{tabular}

Approximately half of the sample employees (46\%) (42\%) and (50.7\%) did not agree with most of the negative effects (organization reputation, Employee morale and Productivity, respectively) of using social networking sites on the organization. It is also can be mentioned here that $41.3 \%$ and $47.3 \%$ of the respondents remain neutral about the possibility of company facing lawsuits, bad publicity and harassment of coworker respectively.

\section{Organizational Policy regarding social networking sites at workplace:}

Table 7: Are employees allowed to get access to social networking at workplace

\begin{tabular}{|l|c|}
\hline Accessibility & Total Responses (frequency) \\
\hline Never & 50 \\
\hline During break time & 37 \\
\hline Access without knowledge of superior & 45 \\
\hline Employer allowed access & 48 \\
\hline Total & 180 \\
\hline
\end{tabular}


50 employees out of 180 sample employees responded their employers never allow them to use social networking sites while they are at the office. Whereas it is also noticeable that 48 $(26.67 \%)$ sample employees responded that their employers allow them to use Social networking sites at the office.

Table 8: Organization implements policy regarding employees' use of SNS at work

\begin{tabular}{|l|c|}
\hline Responses regarding implementation & Responses (in \%) \\
\hline Yes and effective & $32 \%$ \\
\hline No policy & $38 \%$ \\
\hline There is policy but not effective & $25.3 \%$ \\
\hline No idea & $4.7 \%$ \\
\hline
\end{tabular}

The present study reveals that $38 \%$ of the respondents indicated that their organization does not have any policy regarding the use of Social network by its employees at the workplace. While $32 \%$ responded that their organizations effectively implement the policy. While this is also mentionable that $25.3 \%$ of the sample employees' organizations have policies regarding the use of Social network by its employees at the workplace but failed to implement effectively.

\section{Conclusion And Recommendations}

Companies would benefit from a well-communicated and well-planned social networking policy that will cover both the employer and employee rights and obligations.

\section{Employee Responses regarding Policy Recommendations}

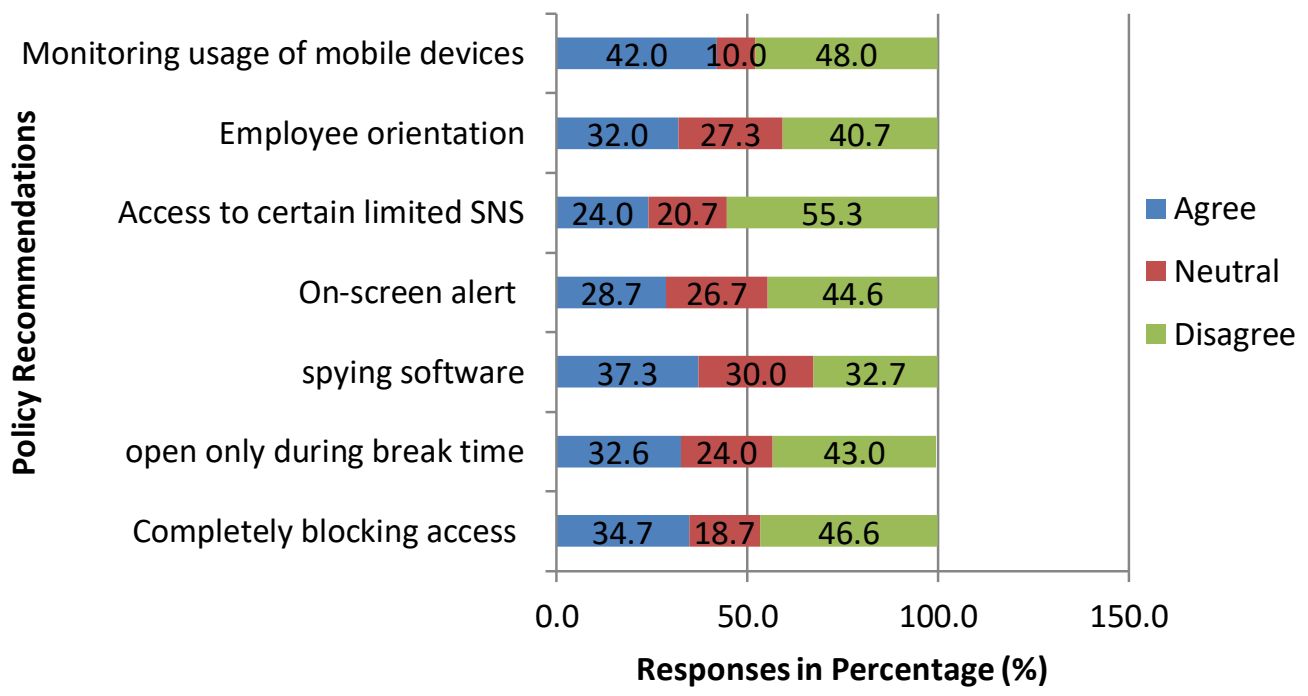

- Companies need to identify an acceptable level of monitoring employee's personal use of social media, without being seen to limit their freedom of expression. 
- The policy guideline needs to emphasize in two main areas: Firstly, an employee's use of social media on behalf of the company and secondly, employees' personal use of social media.

- The policy guidance may also specify that the employees will not be guided in personal activities or opinion as long as they are within the law, not offensive to others or the company. It can also emphasize the need for employees to reflect on their individual responsibility towards the company while using social media.

- The rapid pace of change and development in the use of social media requires the company authority to review the social media guidelines time to time.

Technology change is inevitable. So the management should be aware of the fact that these changes may act for the company if handled with an appropriate tactic. Fighting against the wave of the technology is merely unproductive. It would be rather effective if the management could allow its employees to get access to certain websites to keep them productive and be able to monitor usage of these selected social networking sites.

\section{REFERENCES}

A T \& T. (2008). Social Networking in the Workplace Increases Efficiency.

Al Amin, M. (2015). Workplace Safety: A Necessity or a Luxury in the Micro, Small and Medium Enterprises of Bangladesh?. American Journal Of Trade And Policy, 2(3), 135-142.

Bennett, J., Owers, M., Pitt, M., \& Tucker, M. (2010). Workplace impact of social networking. Property Management, 28(3), pp. 138 - 148.

Boyd D. \& Ellison N. (2007). Social Network Sites: Definition, History, and Scholarship. Journal of Computer-Mediated Communication, 13(1), article 11.

Breslin T. (2009, September). When social networking enters the workplace. Massachusetts Nurse, 80(8), 14. Retrieved fromhttp://ezproxy.neumann.edu:2048/login?url=http://search. ebscohost.com $/$ login.aspx?direct $=$ true $\& \mathrm{db}=\mathrm{a} 9 \mathrm{~h} \& \mathrm{AN}=44347496 \&$ site=ehost-live

Ellison N. B., Steinfield C. \& Lampe C. (2007). The Benefits of Facebook "Friends:" Social Capital and College Students" Use of Online Social Network Sites. Journal of Computer-Mediated Communication, 12, pp. 1143-1168.

Gul, Y. (2014). Effect of Information Technology on Social Movements: A case study of Arab countries. Asian Journal Of Humanity, Art And Literature, 1(2), 84-96.

Leidner D., Koch H.\& Gonzalez E. (2010). Assimilating Generation Y IT New Hires into USAA's Workforce: The Role of an Enterprise 2.0 System. MIS Quarterly Executive, 9(4), pp. 229-242.

Manpower Inc., Employer Perspectives on Social Networking Survey, 2009

Patel, N. \& Jasani, H. (2010). Social Media Security Policies: Guidelines for Organizations. Issues inInformation Systems, XI (1), pp. 628-634.

Peacock L. (2008, April 11). Employers watch Facebook usage. Employers' Law. Retrieved from:http://www.lexisnexis.com/us/lnacademic/results/docview/docview.do?docLinkInd=tru e\&risb=21_T7917082304\&format=GNBFI\&sort=RELEVANCE\&startDocNo=1\&resultsUrlKey=29_

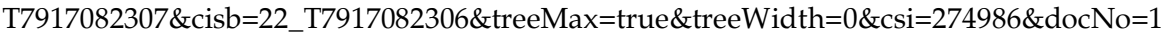

Perera, G., Khatibi, A., \& Navarathna, N. (2015). Relaionship between Employee-Organization Congruence (perceived) and Organizational Commitment in the Sri Lankan Apparel Sector. Asian Business Review, 1(2), 132-135.

Shaker, F. (2015). The Social Network of High and Low Self- Monitors and it's Impact on Organization's Performance. Asian Business Review, 4(3), 22-26.

Wilson J. (2009, June 6). Social networking: the business case. [Electronic Version] Engineering \& Technology (4)10, pp. 54-56.

Wise P. (2009, Summer). Tweet, tweet, you're fired. Employment \& Labor Relations Law. (7)4 7-12. Retrieved from: http://web.ebscohost.com/ehost/detail?vid=6\&hid=106\&sid=57e596aa-f485-44698b18-cf75f1506f86\%40sessionmgr112\&bdata=JnNpdGU9ZWhvc3QtbGl2ZQ $\% 3 d \% 3 d \# d b=a 9 h \& A N=44656323$ 